University of Nebraska - Lincoln

DigitalCommons@University of Nebraska - Lincoln

Faculty Publications from the Harold W. Manter Laboratory of Parasitology

$12-1970$

\title{
Two New Species of Digenea from the Spot, Leiostomus xanthurus Lacépède, from the Gulf of Mexico
}

Robin M. Overstreet

Gulf Coast Research Laboratory, robin.overstreet@usm.edu

Follow this and additional works at: https://digitalcommons.unl.edu/parasitologyfacpubs

Part of the Parasitology Commons

Overstreet, Robin M., "Two New Species of Digenea from the Spot, Leiostomus xanthurus Lacépède, from the Gulf of Mexico" (1970). Faculty Publications from the Harold W. Manter Laboratory of Parasitology. 297.

https://digitalcommons.unl.edu/parasitologyfacpubs/297

This Article is brought to you for free and open access by the Parasitology, Harold W. Manter Laboratory of at DigitalCommons@University of Nebraska - Lincoln. It has been accepted for inclusion in Faculty Publications from the Harold W. Manter Laboratory of Parasitology by an authorized administrator of DigitalCommons@University of Nebraska - Lincoln. 


\title{
TWO NEW SPECIES OF DIGENEA FROM THE SPOT, LEIOSTOMUS XANTHURUS LACÉPÈDE, FROM THE GULF OF MEXICO*
}

\author{
Robin M. Overstreet \\ Gulf Coast Research Laboratory, Ocean Springs, Mississippi 39564
}

ABstract: Two new species of Digenea are described from the euryhaline fish, Leiostomus xanthurus, from near Ocean Springs, Mississippi. The first, Apocreadium manteri, is most like A. uroproctoferum Sogandares-Bernal, 1959, from which it differs by having multispined scales and larger eggs and not possessing a uroproct. The second, Lecithaster leiostomi, is most like L. gibbosus (Rudolphi, 1802) from which it differs primarily by having a more elongated seminal vesicle and stockier vitelline lobes. Lecithaster musteli Srivastava, 1966, is considered a synonym of L. confusus Odhner, 1905.

The following trematodes were collected between October 1969 and April 1970 from the spot, Leiostomus xanthurus Lacépède (Sciaenidae-drum family), a common fish in the Gulf of Mexico and adjacent waters. They were fixed in hot AFA solution under slight pressure and stained with Van Cleave's hematoxylin. Figures were drawn with the aid of a camera lucida and measurements are given in microns.

I acknowledge the assistance of Mr. Ronnie Palmer who helped collect the hosts and parasites.

\section{Apocreadium manteri sp. $\mathrm{n}$. (Figs. 1, 2)}

\section{Description (based on 9 mature specimens)}

Body 2,306 to 4,801 long by 608 to 1,590 wide, usually widest near level of posterior testis. Tegument with blade or trough-shaped scales, each with 1 to 6 embedded spines; scales more dense on forebody, sparse on dorsal portion of hindbody. Eyespot pigment dispersed and sparse. Oral sucker subterminal, without lateral fleshy lobes adjacent to mouth, 233 to 416 long by 219 to 374 wide. Acetabulum 282 to 559 long by 284 to 533 wide. Sucker width ratio $1: 1.3$ to 1.5 . Forebody 20 to $28 \%$ of body length. Prepharynx usually shorter than pharynx. Pharynx 114 to 186 long by 91 to 206 wide. Esophagus either longer or shorter than pharynx depending on its state of contraction, surrounded by numerous glandular cells. Intestinal bifurcation roughly halfway between pharynx and acetabulum; ceca terminating 155 to 356 from posterior end of body.

Testes tandem, contiguous or nearly so, usually slightly irregular in shape; anterior testis 220 to 477 long by 271 to 514 wide with anterior border either slightly anterior or posterior to midbody; posterior testis larger, 281 to 608 long by 290 to

Received for publication 15 May 1970.

* This study was conducted in cooperation with the Department of the Interior, Bureau of Commercial Fisheries, under Public Law 88-309, Project 2-85-R.
524 wide. Posttesticular space 26 to $35 \%$ of body length. Cirrus sac absent. Seminal vesicle saccate, 208 to 542 long by 81 to 215 wide, usually overlapping ovary. Pars prostatica shorter than and extending dorsal to or along either side of acetabulum. Prostatic cells few. Genital atrium tubular. Genital pore median, immediately anterior to acetabulum.

Ovary globular, dextral or occasionally median, roughly midway between anterior testis and acetabulum, 154 to 309 long by 184 to 402 wide. Seminal receptacle either larger or smaller than seminal vesicle, at or near ovarian level. Mehlis' gland between anterior testis and ovary. Laurer's canal present. Vitellaria consisting of numerous follicles, extending between level near base of acetabulum and posterior end of body, occasionally a few follicles overlapping testes. Eggs 84 to 112 long by 58 to 70 wide.

Excretory vesicle terminating anteriorly at or a short distance posterior to rear testis; pore dorsal, subterminal. Lymphatic system inconspicuous with 2 pairs of narrow longitudinal vessels extending most of body length; occasionally branching.

Type host: Leiostomus xanthurus.

Site: Intestine, usually anterior portion.

Locality: Bernard Bayou to Horn Island, near Ocean Springs, Mississippi.

Holotype: USNM Helm. Coll. No. 71477, paratype: No. 71478.

This species is named in honor of Dr. Harold W. Manter.

\section{DISCUSSION}

This species apparently differs from the other eight species of Apocreadium, except A. foliatum (Siddiqi and Cable, 1960) Overstreet, 1969, by having multispined scales. I reexamined specimens of A. foliatum and found the undescribed multispined scales present. Some specimens of both species, however, have the majority of the scales containing a single spine. Apocreadium manteri differs from A. foliatum by having a shorter posttesticular space, a greater sucker width ratio, and more anteriorly extending vitelline follicles. In relation to these 

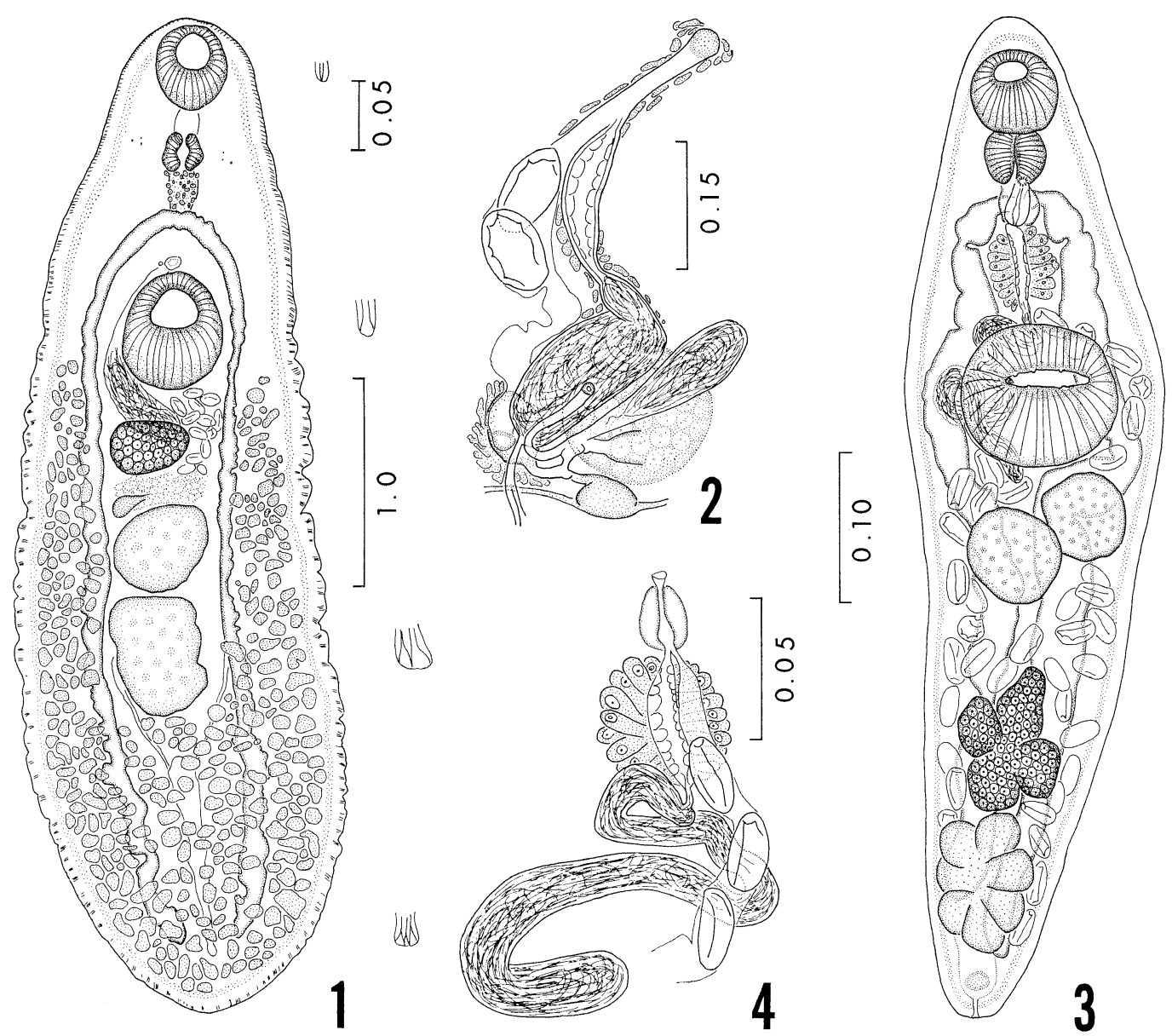

Figures 1-4. 1. Apocreadium manteri, holotype, ventral view. Enlarged scales shown on right. 2. Apocreadium manteri, terminal genitalia, ovary, and adjacent organs, dorsal view. 3. Lecithaster leiostomi, holotype, ventral view. 4. Lecithaster leiostomi, terminal genitalia, ventral view. Scale values are millimeters.

and other features, it is most similar to A. uroproctoferum Sogandares-Bernal, 1959, from which it can be separated by having eggs 84 to 112 by 58 to 70 rather than 64 to 80 by 40 to 45 and not possessing a uroproct.

The lymphatic system, especially in the hindbody, is difficult or impossible to see in some individuals of several species of Apocreadium. Even though it is the only character used to distinguish Apocreadium from Homalometron, both A. synagris Yamaguti, 1953, and A. caballeroi Bravo-Hollis, 1954, were described without the system being evident. Fischthal and Kuntz (1965) have since reported its presence in the former species. On the other hand, if H. caballeroi Lamothe, 1965, is shown to have a lymphatic system, that species could be con- sidered a synonym of A. balistis Manter, 1947. Dactylotrema squamatum Bravo-Hollis and Manter, 1957, also has similar scales on the tegument. The presence of multispined scales on A. manteri and A. foliatum is additional morphological evidence for placing Apocreadium into the Homalometroninae, in which Dactylotrema is a member, as suggested by Manter (1947), but not followed by all recent workers. I follow the lepocreadiid classification of Howell (1966).

\section{Lecithaster leiostomi sp. $\mathrm{n}$.} (Figs. 3, 4)

Description (based on 20 mature specimens)

Body fusiform, 389 to 923 long by 138 to 253 wide; widest at or posterior to acetabular level. Tegument smooth. Oral sucker subterminal, 49 to 
81 long by 54 to 88 wide. Acetabulum 81 to 140 long by 88 to 154 wide. Sucker width ratio $1: 1.6$ to 1.8 . Forebody 121 to 270 long or 26 to $39 \%$ of body length. Prepharynx absent. Pharynx 33 to 54 long by 37 to 60 wide. Esophagus approximately as long as pharynx but usually distorted, without chitinous "wall." Intestinal bifurcation roughly halfway between oral sucker and acetabulum. Ceca dorsal; terminating near posterior end of body, usually beyond vitellarium.

Testes ovoid, smooth, symmetrical or diagonal, separated or contiguous, partially or entirely postacetabular; left testis 51 to 98 long by 49 to 102 wide; right testis 51 to 107 by 47 to 105 . Seminal vesicle narrow, usually more than 3 times longer than acetabulum, sinuous, dorsal or lateral to acetabulum. Pars prostatica lined with vesicular cells, surrounded by large conspicuous prostatic cells; complex approximately same size as pharynx. Sinus sac muscular; containing hermaphroditic duct; duct uniform in width or locally constricted. Genital pore median or submedian, at or near pharyngeal level.

Ovary 51 to 170 long by 58 to 114 wide, its center $1 / 4$ to $1 / 3$ body length from posterior end, near or contiguous with testes and vitellarium, deeply 4-lobed; lobes rounded or irregular in shape, generally as long as wide. Vitellarium rosette-shaped, with 7 lobes slightly longer than wide, approximately same size as ovary. Postvitelline space 4 to $13 \%$ of body length. Seminal receptacle ovoid, dorsal or occasionally lateral to ovary, approximately size of ovarian lobe. Uterus usually extending posteriorly to about middle of, occasionally beyond, vitellarium; with short metraterm joining posterior of sinus sac. Eggs 26 to 36 long by 14 to 21 wide, up to 25 wide in living specimens.

Excretory vesicle bifurcating near acetabular level; arms seldom reaching near pharyngeal level, not united; pore terminal.

Type host: Leiostomus xanthurus.

Site: Usually intestine, occasionally rectum or pyloric ceca.

Locality: Bernard Bayou to Horn Island, near Ocean Springs, Mississippi.

Holotype: USNM Helm. Coll. No. 71479; paratype: No. 71480.

This species is named after the type host.

\section{DISCUSSION}

Lecithaster leiostomi differs from L. extralobus H. Srivastava, 1935, a species which has an elongated seminal vesicle, by having four rather than five ovarian lobes and seven rather than eight vitelline lobes. In L. testilobatus Manter, 1969, the vesicle is an elongated sac but the testes each have four lobes. Lecithaster leiostomi is most similar to L. gibbosus ( $\mathrm{Ru}-$ dolphi, 1802) Lühe, 1901, and L. tauricus Pigulevskii, 1938, from which it can be most easily distinguished by having an elongated rather than spherical or pyriform-shaped seminal vesicle. The eggs in L. leiostomi are larger than in L. tauricus and the smallest overlap the largest ones from L. gibbosus. Variation occurs in the vitelline lobes of $L$. gibbosus, but they are typically slender rather than stocky as in the present species. I doubt that the specimens discussed by Manter (1931) are L. gibbosus.

The genus Lecithaster was reviewed and emended by L. P. Srivastava (1966) to include a species with a genital atrium, constricted hermaphroditic duct, and cirrus. I interpret the region of the terminal ducts in L. musteli Srivastava, 1966, to be basically the same as in other species in the genus, with what is called the hermaphroditic pouch as the sinus sac and the cirrus as the sperm or ejaculatory duct. In any event, the cirrus, a questionable organ in the true sense in hemiurids, is a terminal protrusible organ. I consider L. musteli a synonym of L. confusus Odhner, 1905. The only consistent difference between descriptions of the two species is the larger size of eggs in L. musteli ( 18 to 21 by 12 to 15 compared with 15 to 17 by 7 to 9 ), and I do not consider that difference great enough to justify L. musteli as a separate species.

\section{LITERATURE CITED}

Fischthal, J. H., AND R. E. Kuntz. 1965. Digenetic trematodes of fishes from North Borneo (Malaysia). Proc. Helm. Soc. Wash. 32: 63-71.

Howell, M. 1966. A new genus in the family Lepocreadiidae (Trematoda: Digenea) with notes on the status of some taxa within the family. Tr. Roy. Soc. N. Z., Zool. 8: 2329.

Manter, H. W. 1931. Some digenetic trematodes of marine fishes of Beaufort, North Carolina. Parasitology 23 : 396-411.

1947. The digenetic trematodes of marine fishes of Tortugas, Florida. Am. Midl. Nat. 38: $257-416$.

Srivastava, L. P. 1966. The morphology of Lecithaster musteli sp. nov. (Digenea: Hemiuridae) from the intestine of Onos mustelus (L.) and a review of the genus Lecithaster Lühe, 1901. Parasitology 56: 543-554. 